\title{
Evaluation of elite white clover germplasm under rotational cattle and sheep grazing
}

\begin{abstract}
Four white clover (Trifolium repens L.) cultivars, 4 pre-release cultivars and 24 breeding lines were evaluated in small plots in mixed species swards under rotational cattle and sheep grazing for 2 years. There was no significant stock class $\mathrm{x}$ line interaction for proportion of clover in the sward. There was no evidence that medium- and smallleaved types yielded better under shecp grazing while larger-leaved types yielded better under cattle grazing. Lines with the highest clover content tended to be large leaved and upright irrespective of stock class. They also had moderate to high stolon growing point densities. Breeding programmes have developed lines with high stolon growing point densities, ensuring vegetative persistence, while still maintaining a high proportion of clover in the sward. These pre-release cultivars and breeding lines gave significantly better clover contents than existing cultivars.
\end{abstract}

Keywords cultivars, selections, plant habit, cyanogenesis, stolon growing point density, clover content, cattle grazing, sheep grazing

\section{Introduction}

White dover is grown in most New Zealand pastures predominantly as a nitrogen source, through nitrogen fixation, and to improve sward quality. The proportion of dover in swards is, however, often lower than the desired 30\% proposed by Davies \& Levy (193 1). Standardised measurements of grazed pastures at 11 geographically dispersed sites throughout New Zealand showedclovercontents tovaryfrom 12 to398 (Radcliffe 1974).

Overseas studies have shown that while grazing by sheep reduces dover content in mixed swards compared with cutting management (Newton \& Davies 1987), cattle grazing has a rclatively neutral effect (Frame \& Newbould 1986). Sheep actively select clover in preference to grass (Lancashire \& Keogh 1968), though cattle do not (Briseno de la Hoz \& Wilman 1981). It is therefore inferred that sheep exert greater selective pressures on clover than do cattle (Frame \& Newbould 1986; Newton \& Davies 1987). The present study cannot provide critical evidence for this but will rather evaluate the performance of a range of elite white clover germplasm under these two stock dasses.

\section{Materials and Method}

Plant material

The four white clover cultivars, 'Grasslands Huia', 'Grasslands Pitau', Grasslands Tahora' and 'Grasslands Kopu', were compared with 4 pre-release cultivars, G23, G26, G39 and G49, and 24 breeding lines (Table 1). The breeding lines included 12 selections made from a collection of 130 lines from south-western Europe (Caradus et al. 1990a). These selections were based on 12 geographical areas of origin, such that the best genotypes from the highest yielding populations within each geographical area were selected and polycrossed. Seed was bulked by geographical area to get the 12 breeding lines.

\section{Trial design}

The 32 cultivars and breeding lines were planted into grass swards in autumn 1989 at 2 sites. Palmerston N orth was mob-stocked with sheep. The other site at Aorangi Research Station, on the Kairanga Plains was located in a farmlet rotationally grazed by Friesian bulls at $7.4 \mathrm{per} / \mathrm{ha}$.

Several months before planting volunteer white clover was removed from swards using a selective herbicide, Banvel, applied at the rate of $10 \mathrm{~m} / \mathrm{l}$. Ten 2month-old seedlings wereplanted into I-m rows, with 1 $\mathrm{m}$ spacing between rows and $0.5 \mathrm{~m}$ spacing between traverses. There were 5 replicates arranged in a randomised block design.

Trial sites were temporarily fenced for 6 weeks to allow plant establishment. Then trials weresubjected to the grazing management of the surrounding paddock. At Palmerston North there were 7 grazings in the first year and 10 in thesecondyearwithintervals betweengrazings 
Table 1 Proportion of dover in sward, dover dry weight, leaf number density. stolon growing point density and leaflet width of lines. Values are means of 2 years and 2 sites.

\begin{tabular}{|c|c|c|c|c|c|c|c|}
\hline $\begin{array}{l}\text { Line } \\
\text { NO. }\end{array}$ & Name & Description of cultivar or line & $\begin{array}{l}\text { Proportion } \\
\text { clover }\end{array}$ & $\begin{array}{l}\text { Clover dry } \\
\text { weight } \\
\left(g / m^{2}\right)\end{array}$ & $\begin{array}{l}\text { Leaf No. } \\
\text { density } \\
\left(n o / m^{2}\right)\end{array}$ & $\begin{array}{l}\text { Leaflet width } \\
\quad(\mathbf{m m})\end{array}$ & $\begin{array}{l}\text { Stolon growing } \\
\text { point density } \\
\left(\mathrm{no} / \mathrm{m}^{2}\right)\end{array}$ \\
\hline 1 & Huia & $\begin{array}{l}\text { General purpose cultivar for a wide range of } \\
\text { environments }\end{array}$ & 0.28 & 26 & 4178 & 17.1 & 1850 \\
\hline 2 & Pitau & Winter active selection from Huia $\times$ Spain crosses & 0.26 & 27 & 3330 & 23.0 & 1600 \\
\hline 3 & Kopu & $\begin{array}{l}\text { Selected for improved summer growth and stem } \\
\text { nematode resistance from Pitau } \times \text { ladino crosses }\end{array}$ & 0.26 & 23 & 2595 & 26.6 & 1780 \\
\hline 4 & Tahora & Selected from moist hill country ecotypes & 0.17 & 15 & 3075 & 13.0 & 2760 \\
\hline 5 & G.23 & Selection for improved cool season growth & 0.37 & 37 & 4095 & 24.2 & 1340 \\
\hline 6 & G.26 & Southland selection for good all year performance & 0.30 & 29 & 4610 & 16.2 & 3260 \\
\hline 7 & G.39 & Kaikohe selection from local sheep/beef farms & 0.30 & 29 & 6295 & 16.6 & 3810 \\
\hline 8 & G.49 & Stem nematode resistant selection from Pltau & 0.40 & 37 & 5600 & 23.7 & 2120 \\
\hline 9 & Nematode. small & $\begin{array}{l}\text { Bulk of glasshouse screen for root knot/clover cyst } \\
\text { nematodes. small leaf }\end{array}$ & 0.26 & 25 & 5343 & 16.7 & 3260 \\
\hline 10 & Nematode. large & $\begin{array}{l}\text { Bulk of glasshouse screen for root knot/clover cyst } \\
\text { nematodes. large leaf }\end{array}$ & 0.31 & 35 & 4636 & 22.2 & 1520 \\
\hline 11 & $N Z \times$ USA & Selected for summer growth & 0.39 & 31 & 4365 & 22.2 & 1930 \\
\hline 12 & Sthland & Bulk of local southland ecotypes & 0.26 & 26 & 4366 & 16.8 & 2750 \\
\hline 13 & Frost. small & Selected for frost tolerance. small leat & 0.06 & 7 & 1223 & 13.1 & 1500 \\
\hline 14 & Frost. large & Selected for frost tolerance, large leat & 0.19 & 20 & 3060 & 14.5 & 1560 \\
\hline 15 & Huia $\times$ Hill & Selection for good all year production & 0.30 & 30 & 5555 & 15.0 & 2940 \\
\hline 16 & Huia $\times$ Sthland & Very active spring/summer growth & 0.32 & 22 & 5280 & 13.0 & 3630 \\
\hline 17 & N Line & Selected for tolerance to mineral nitrogen & 0.25 & 21 & 2703 & 19.7 & 1660 \\
\hline 18 & Huia re-seln & Re-selection from Huia & 0.33 & 33 & 4120 & 19.9 & 1610 \\
\hline 19 & $\begin{array}{l}\text { Stoloniferous } \\
\text { seln }\end{array}$ & $\begin{array}{l}\text { Selection for high stolon densities in medium to } \\
\text { large leal type }\end{array}$ & 0.40 & 39 & 4880 & 22.2 & 2610 \\
\hline 20 & Gene Pool A & $\begin{array}{l}\text { Bulk of selection for good first year growth in } \\
\text { spaced plants }\end{array}$ & 0.46 & 52 & 6043 & 23.7 & 1900 \\
\hline 21 & Sth Eur. $1^{\bullet}$ & $\begin{array}{l}\text { Selected from very early flowering Portuguese } \\
\text { material }\end{array}$ & 0.30 & 26 & 3633 & 21.4 & 1620 \\
\hline 22 & Sth Eur. II & Selected from early flowering Portuguese material & 0.26 & 24 & 3875 & 20.6 & 2130 \\
\hline 23 & Sth Eur. $111 *$ & Selected from material collected in Central Italy & 0.24 & 19 & 3790 & 16.6 & 1920 \\
\hline 24 & Sth Eur. IV 1 & $\begin{array}{l}\text { Selected from material from north coastal Galicia. } \\
\text { Asturias and Cantabrian }\end{array}$ & 0.37 & 34 & 4670 & 19.0 & 2260 \\
\hline 25 & Sth Eur. $\mathrm{V} *$ & Selected from material collected from Lodi, Italy & 0.32 & 27 & 2733 & 23.4 & 1500 \\
\hline 26 & Sth Eur. VII $\bullet$ & $\begin{array}{l}\text { Selected from material collected from high } \\
\text { altitude. north Italy }\end{array}$ & 0.21 & 20 & 3266 & 15.4 & 2070 \\
\hline 27 & Sth Eur. VI $\bullet$ & $\begin{array}{l}\text { Selected from material collected from low altitude. } \\
\text { north Italy }\end{array}$ & 0.24 & 24 & 3375 & 19.1 & 1920 \\
\hline $2 s$ & Sth Eur. VIII - & $\begin{array}{l}\text { Selected from material collected from unimproved } \\
\text { farms, north Portugal }\end{array}$ & 0.24 & 22 & 3493 & 17.7 & 2590 \\
\hline 29 & Sth Eur. IX & $\begin{array}{l}\text { Selected from material collected from improved } \\
\text { farms. north Portugal }\end{array}$ & 0.27 & 26 & 3285 & 21.5 & 1920 \\
\hline 30 & Sth Eur. $X *$ & $\begin{array}{l}\text { Selected from material collection from low altitude } \\
\text { inland Galicia. Spain }\end{array}$ & 0.30 & 26 & 3480 & 21.3 & 2060 \\
\hline 31 & Sth Eur. XI + & $\begin{array}{l}\text { Selected from material collected from high altitude } \\
\text { inland Galicia. Spain }\end{array}$ & 0.28 & 24 & 3600 & 17.1 & 2070 \\
\hline 32 & Sth Eur. XII & $\begin{array}{l}\text { Selected from material collected on Crau Plains, } \\
\text { southern France }\end{array}$ & 0.26 & 25 & 2660 & 21.0 & 1190 \\
\hline$P$ & & & $\ldots$ & $\ldots$ & $\ldots$ & $\cdots$ & $\cdots$ \\
\hline \multicolumn{3}{|c|}{$\operatorname{LSD}_{0.00}$} & 0.09 & 10 & 1550 & 2.1 & 866 \\
\hline
\end{tabular}


ranging from 24 days in spring to 60 days in winter. At Aorangi there were 9 grazings in year 1 and 10 in year 2 .

\section{Measurements}

At the end of years 1 and 2, in autumn, a $400 \mathrm{~cm}^{2}$ quadrat was harvested to $1 \mathrm{~cm}$ height, from each plot at each site. The entire sample was sorted into whiteclover and other species, which was predominantly perennial ryegrass. White dover leaves were separated from any harvested stolon and counted. White clover leaves, stolons and other species were weighed dry. At Palmerston North, before both harvests, aerial and surface stolon growing point densities were counted once per plot using a 100 $\mathrm{cm}^{2}$ qttadrat. Stolon growing points included all axillary buds with art open leaf. Leaf size was determined by the width of the terminal leaflet of the second open leaf along a stolon from the tip of 30 plants per line grown as spread plants at Palmerston North. Percentage of genotypes exhibiting a cyanogenic reaction was determined by testing 20 genotypes using the picrate method (Corkill 1940).

\section{Data analysis}

Proportion of dover in the sward, total harvested dover dry weight, total dry weight harvested, and leaf number density (number/ $\mathrm{m}^{*}$ ) were calculated and lines, sites and years compared by a split plot in time analysis of variance. Transformation, either log or arcsin square root, was used were appropriate. Lines were dustered using mean morphological and agronomic data into groups whichminimiscd the total within-groups sums of squares. Analyses were conducted using GENSTAT.

\section{Results}

\section{Description of lines}

The leaf size of cultivars and prerelease cultivars were in the expected order with G.23, Kopu largest and Tahora smallest (Table 1). Other large-leaved lines included G.49, lines 10, 11, 19, 20 and 25. The smallleaved types induded not only Tahora but also lines 13 -
16 which included the frost tolerant selections and crosses between Huia and ecotypes from regions predominantly grazed by sheep. Stolon growing point density was generally negatively associated with leaf size $(r=-0.50, P<0.01)$.

\section{Agronomic performance}

For all characters there was no significant ( $P>0.05$ ) variation among lines in their level of performance under either sheep or cattle grazing in both years. At a significance level of $10 \%$ there was a line $x$ site $x$ year interaction for proportion of clover. This was predominantlydue to theexceptionallypoorperformanceof line 32 in the second year at Aorangi. when it had only $18 \%$ of the clover content in year 1 , whereas at Palmerston North it showed no change from year 1 to year 2 .

There was no significant line $x$ site interaction for any of the characters measured. The main effect of lines was significant $(\mathrm{P}<0.001)$ for all characters with the exception of total clover and grass dry weight (Table $1)$. Lines with consistently high proportion of clover were G.49, large-leaf stoloniferous (19), and Gene Pool A (20), while those with consistently low proportion of dover were Tahora, and the small- and large-leaf frost tolerant selections (13 and 14). Comparison of lines grouped on the basis of proportion of clover showed that the best lines were large leaved and highly cyanogenic with a high leaf number density (Table 2). There was, however, no significant difference between the groups for stolon growing point density. White clover cultivars are often characterised by leaf size into small-, medium- and large-leaved groups (Caradus et al. 1989). In the present study lines with a leaflet width $\leq 15 \mathrm{~mm}$ were considered small leaved, $>15$ $\mathrm{mm} \leq 19 \mathrm{~mm}$ medium leaved and $>19 \mathrm{~mm}$ large leaved (Table 1). Among the small-leaved lines, line 15 and 16 had significantly $(\mathrm{P}<0.05)$ greater dover contents than the current small-leaved cultivar Tahora. Among the medium-leaved lines none were significantly better than Huia, although line 24 gave a $32 \%$ increase in clover content. Among the largeleaved types, lines 5,8,1 1, 19 and 20 showed a significant improvement over either Pitau or Kopu.

Table 2 Comparison of lines grouped on the basis of proportion of clover in sward.

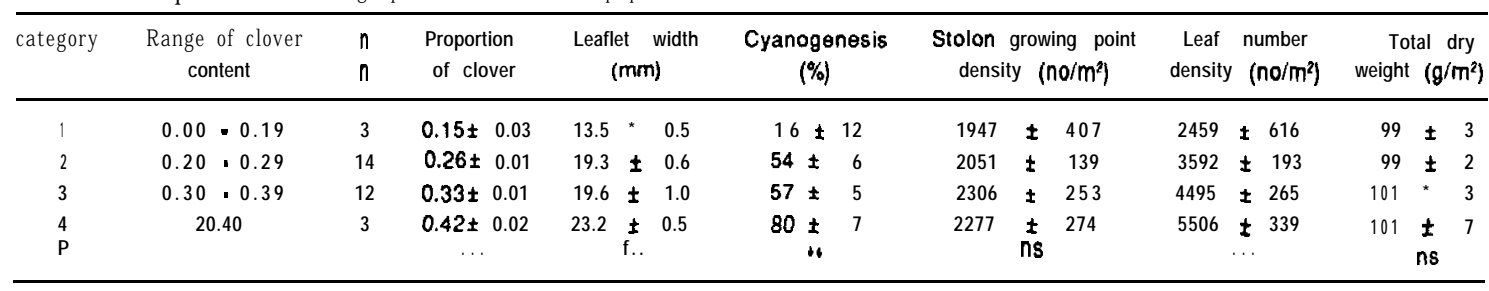


Table 3 Lists of cultivars and lines in 6 groups derived using cluster analysis, with means and standard errors for each plant character of cultivars and lines within clusters.

\begin{tabular}{|c|c|c|c|c|c|c|}
\hline \multirow{2}{*}{ Plant Character } & \multicolumn{6}{|c|}{ Cluster } \\
\hline & $A$ & B & C & D & $E$ & $\mathrm{~F}$ \\
\hline & $\begin{array}{l}\text { G.26 } \\
\text { G.39 } \\
\text { Nematode, small } \\
\text { Huia } \times \text { Hill } \\
\text { Huia } \times \text { Southland } \\
\text { Stolonifarous sel }\end{array}$ & $\begin{array}{l}\text { G. } 49 \\
\text { Gene Pool A }\end{array}$ & $\begin{array}{l}\text { Tahora } \\
\text { A Southland } \\
\text { Sth. Eur. V }\end{array}$ & $\begin{array}{l}\text { Huia } \\
\text { G. } 23 \\
\text { Nematode, large S } \\
\text { NZ x USA } \\
\text { Huia reseln } \\
\text { Sth Eur. IV }\end{array}$ & $\begin{array}{l}\text { Pitau } \\
\text { Frost, Iarge } \\
\text { Sth Eur. I } \\
\text { Sth Eur. II } \\
\text { Sth Eur. III } \\
\text { Sth Eur. VI } \\
\text { Sth Eur. VII } \\
\text { Sth Eur. IX } \\
\text { Sth Eur. X } \\
\text { Sth Eur. XI }\end{array}$ & $\begin{array}{l}\text { Kopu } \\
\text { Frost, small } \\
\text { N Line } \\
\text { Sth Eur. V } \\
\text { Sth Eur. XII } \\
\end{array}$ \\
\hline \multicolumn{7}{|l|}{ Spaced plants } \\
\hline $\begin{array}{l}\text { Leaflet width }(\mathrm{mm}) \\
\% \quad \text { cyanogenesis }\end{array}$ & $\begin{array}{l}16.6 \pm 1.2 \\
64 \pm 4\end{array}$ & $\begin{array}{l}23.7 \pm 1.2 \\
66 \pm 6\end{array}$ & $\begin{array}{l}15.6 \pm 1.4 \\
50 \pm 6\end{array}$ & $\begin{array}{l}20.6 \pm 1.1 \\
63 \pm 4\end{array}$ & $\begin{array}{l}19.2 \pm 0.9 \\
44 \pm 9\end{array}$ & $\begin{array}{l}20.6 \pm 2.2 \\
42 \pm 13\end{array}$ \\
\hline \multicolumn{7}{|l|}{ Sward plants } \\
\hline $\begin{array}{l}\text { Stolon growing point density }\left(\mathrm{no} / \mathrm{m}^{2}\right) \\
\text { Leaf number density (no/m) } \\
\text { Harvested clover dry weight }\left(\mathrm{g} / \mathrm{m}^{2}\right) \\
\text { Propn of clover in sward }\end{array}$ & $\begin{array}{l}3266 \pm 157 \\
5377 \pm 101 \\
29 \pm 2 \\
0.32 \pm 0.02\end{array}$ & $\begin{array}{l}2010 \pm 110 \\
5633 \pm 221 \\
44 \pm 6 \\
0.43 \pm 0.03\end{array}$ & $\begin{array}{l}2700 \pm 55 \\
3645 \pm 361 \\
21 \pm 3 \\
0.23 \pm 0.03\end{array}$ & $\begin{array}{l}1765 \pm 132 \\
4376 \pm 127 \\
33 \pm 2 \\
0.34 \pm 0.02\end{array}$ & $\begin{array}{l}1889 \pm 67 \\
3490 \pm 65 \\
24 \pm 1 \\
0.26 \pm 0.01\end{array}$ & $\begin{array}{l}1526 \pm 99 \\
2423 \pm 303 \\
20 \pm 4 \\
0.23 \pm 0.04\end{array}$ \\
\hline
\end{tabular}

\section{Classification of lines}

Cluster analysis was used to group lines into 6 clusters (Table 3). There were significant differences among clusters for all characters except percent cyanogenesis. Cluster A contained lines characterised by a very high stolon growing point density and high clover content; cluster $\mathbf{B}$ was characterised by very high clover content and very large leaves but only moderate stolon growing point density; cluster $\mathrm{C}$ by small leaves and lower clover content but high stolon growing point density; cluster D by low stolon growing point density but high clover content; cluster $\mathrm{E}$ by low leaf number density; and cluster $\mathrm{F}$ by very low stolon growing point density and low clover content (Table 3).

\section{Discussion}

Despite large differences among the lines studied for plant type (Table 1), there was no significant stock class $\mathrm{x}$ line interaction for whiteclover content. It is generally considered that of the three broad cultivar groupings, large-, medium- and small- leaved, the larger-leaved types are best able to withstand less frequent lax grazing systems whereas low-growing small-leaved cultivars are adapted to withstand frequent close defoliation (Harris 1987). There was no evidence that medium- and small-leaved types yielded better under sheep grazing while larger-leaved types yielded better under cattle grazing. Apparently the intensity of grazing was similar under both stock classes since both were rotationally grazedwithnomorethan 10 defoliations peryear. It was evident that lines with the highest clover content tended to be larger leaved and upright irrespective of stock class. They also had moderate to high stolon growing point densities, for example, compare Pitau and Kopu with the highclovercontentlines G.49,NZx USA, large leaf stoloniferous and Gene Pool A (Table 1).

Significant management system $\mathrm{x}$ white clover line interactions for clover content have been shown in other studies but comparisons in these cases were between setstocking and rotational grazing (Brock 1988) or cutting versus continuous sheep grazing (Evans \& Williams 1984). not between stock classes. Few studies have compared two or more white clover lines under different stock classes. Williams et al. (1982) compared four lines, Pitau, Huia, hill country selection and a 'wild' ecotype, under rotational cattle and sheep and set-stock sheep grazing. They found that line differences were greatest under set-stocking by sheep, smallest under rotational cattle grazing and intermediate under rotational grazing by sheep. The small-leaved stoloniferous hill country selection gave the best clover contents in all management systems, but the larger-leaved Pitau persisted only under rotational cattle grazing.

High stolon growing point densities are expected to conferanadvantageinpersistencesincestolonproduction is essential for vegetative survival of white clover (Beinhart 1963). A number of studies have, however, shown that the 'penalty' for high stolon growing point density may be a reduction in harvested clover yield (Rhodes \& Harris 1979). In the present study there was no correlation between stolon growing point density and either proportion of clover in the sward $(r=0.11, n . s)$ or absolute white clover yield ( $r=0.01, n . s$.). This was due predominantly to high yields of lines (e.g. large leaf 
stoloniferous, Huia x Hill, G26, G.39, Nematode-small and Huia $\times$ Southland) which also had high stolon growing point densities, and low yields of some lines (e.g. Frost tolerant-small and large, and Sth. Eur. XII) which also had low stolon growing point densities.

While it is often thought that year-to-year variation in clover content is more variable than site-to-site (Harris 1987) this was not necessarily the case in the present study. Both at Aorangi and Palmerston North year 1 and year 2 data were correlated ( $r-0.55$ and 0.54 respectively, $(\mathrm{P}<0.01)$. In year 1 , the 2 sites were better correlated than in year 2 ( $r=0.57, P<0.01$ and $r=0.38$, $P<0.05$, respectively), suggesting that it may be a matter of time before a site $x$ line interaction becomes evident.

Selections for frost tolerance (lines 13 and 14), while successfully ensuring frost tolerance (Caradus $\boldsymbol{e t}$ al. 1990b), have resulted in lines with relatively poor yields. This is in itself an adaptation, with a low leaf number (Table 1) resulting in a reduced leaf tissue mass exposed directly to frost. Low cyanogenesis of the frost tolerant selections is a further adaptation aiding frosttolerance (Foulds \& Young 1977).

Only two of the lines studied (25 and 30 ) could be classified as ladino type on account of having large leaves and being acyanogenic (Caradus $\boldsymbol{e t}$ al. 1989). Both of these lines produced reasonable dover contents (Table 1) and were comparable with current largeleaved cultivars available Ladino types are generally considered to be open in habit and intolerant of frequent grazing showing poor persistence after the first year (Williams 1987). It would, however, appear that selection5 can be made within the ladino type for lines which give consistently good dover yields.

It appears that at least in the first 2 year 5 of growth white clover lines perform similarly under both rotational sheep androtational cattle grazing. Breeding programmes have successfully identified and produced pre-release cultivars and breeding lines giving significantly better dover content5 than existing cultivars.

\section{ACKNOWLEDGEMENTS}

To Allison MacKay, Claire Youngs, and Liz Winder for technical assistance, and Yvonne Gray, Christine van Meer and Margaret Greig for assistance with herbage analysis.

\section{REFERENCES}

Beinhart, G. 1963. Effects of environment on meristematic development, leaf area, and growth of white clover. Crop science 3: 209-213.

Briseno de la Hoz, V.M.; Wilman D. 1981. Effects of cattle grazing, sheep grazing, cutting and sward height on a grass/ white clover sward. Journal of agricultural science 97: 699-706.

Brock, J.L. 1988. Evaluation of New Zealand bred white clover cultivars under rotational grazing and set stocking with sheep. Proceedings of the New Zealand Grassland Association 49: 203-206.

Caradus, J.R.; Mackay, A.C.; Woodfield, D.R.; van den Bosch, J.; Wewala, G.S. 1989. Classification of a world collection of white clover cultivars. Euphytica 42: 183-196.

Caradus. J.R.; Forde, M.B.; Wewala, S.; Mackay, A.C. 1990a. Description and dassification of a white clover (Trifolium repens L.) germplasm collection from southwest Europe. New Zealand Journal of agricultural research 33: 367-375.

Caradus, J.R.; Mackay, A.C.; van den Bosch, J.; Wewala, S.; Greer, D.H. 1990b. Heritability of frost tolerance in white clover (Trifolium repens L.). Journal of agricultural science 114: 151-155.

Corkill, L. 1940. Cyanogenesis in white clover (Trifolium repens L.) I. Cyanogenesis in single plants. New Zealand journal of science and technology $22 B: 65$ 67.

Davies, W.; Levy, E.B. 1931. Strain investigation of grass and clovers. 4. White clover (Trifolium repens). New Zealand journal of agriculture 42: 73-89.

Evans, D.R.; Williams, T.A. 1984. Evaluation of white clover under grazing: morphological characters. Welsh PlantBreeding Station. Annual Report 1983, pp 44-46.

Foulds, W.; Young, L. 1977. Effect of frosting, moisture stress and potassium cyanide on the metabolism of cyanogenic and acyanogenic phenotypes of Lotus corniculatw L. and Trifolium repens L. Heredity38: $19-24$.

Frame, J.; Newbould. P. 1986. Agronomy of white clover. Advances in agronomy 40: I-88.

Harris, W. 1987. Population dynamics and competition. In M.J. Baker and W.M. Williams (eds). White clover. CA B International. Pp 203-297.

Lancashire, J.L.; Keogh, R.G. 1968. Fadial eczema and grazing management. Massey Sheepfarming Annual, pp 29-35.

Newton, J.E.; Davies, D.A. 1987. White clover and sheep production. In G.E. Pallott (ed). Efficient sheep production from grass. British Grassland Society, Occasional Symposium 21: 79-87.

Raddliffe, J.E. 1974. Seasonal distribution of pasture production in New Zealand. I. Methods of measurement. NZ journal of experimental agriculture 2: 337-340.

Rhodes, I.; Harris, W. 1979. The nature and basis of differences in sward composition and yield in ryegrass - white clover mixtures. In A.H. Charles 
(ed). Changes in sward composition and productivity. British Grassland Society Occasional Symposiwn 10: $55-60$.

Williams, W.M. 1987. Adaptive variation. In M.J. Baker and W.M. Williams (eds). White clover. CAB International. Pp 299-321.

Williams, W.M.; Lambert, M .G.; Caradus, J.R. 1982. Performance of a hill country white dover selection. Proceedings of the New Zealand Grassland Association 43: 188-195. 